\title{
Strengthening Food Security Institution of Poverty of Fishermen in Indonesia
}

\author{
Ansar Arifin ${ }^{1}$, Haslinda B. Anriani ${ }^{2}$, Harifuddin Halim $^{3}$, Rasyidah Zainuddin ${ }^{4}$, \\ Ismail Suardi Wekke 5 \\ \{iswekke@gmail.com $\left.{ }^{5}\right\}$ \\ Universitas Hasanuddin Makassar ${ }^{1}$ \\ Universitas Tadulako Palu ${ }^{2}$ \\ Universitas Pejuang RI Makassar $^{3}$ \\ Universitas Bosowa Makassar ${ }^{4}$ \\ IAIN Sorong ${ }^{5}$
}

\begin{abstract}
This article describes the strengthening of household food security institutions of poverty of fishermen according to developments. The sample of this research is poor fisherman's household that analyzed descriptively. The collecting data technique using literature study. The results showed that traditional food security institutions have existed since long ago as a form of adaptation to the problem of poverty. Growing population and increasing demand for food require local and modern food-based food security management.
\end{abstract}

Keywords: food security, strengthening institution, poverty, fishermen

\section{Introduction}

The problem of poverty is already a global issue that is directly related to humanity and has drained many experts to formulate the concept of settlement. One opinion that emerges is Ickis' opinion that poverty is closely linked to rural development strategies [1]. Thus Ickis proposed four strategies for poverty reduction, one of them is the welfare strategy related to food security [1].

Food security at the national level is a nation's ability to ensure that all citizens receive sufficient quantities of food, decent, safe, and halal quality, based on optimization of use and based on the diversity of domestic resources [2]. One indicator to measure food security is the dependence and availability of national food on imports.

Food security has become a central issue within the framework of national development. However, adequate national food supply does not necessarily guarantee food security at the regional and household level and individuals. Although the national food supply is sufficient, the emergence of cases of food insecurity and the discovery of infants and children under five malnutrition in various regions in Indonesia is an undeniable fact. This condition is also confirmed by Suryana [3] that although Indonesian macro is able to provide enough food to meet the needs of its citizens, the quality of food consumption the average Indonesian society is not under the recommendation of nutritionists yet.

Food security is related to the condition of the fulfillment of food for the household which is reflected the availability of adequate food, both quantity, and quality, safe, equitable, and 
affordable [4]. This is, of course, related to many factors, including the type of food, production, and distribution. More important, however, are the social norms that operate governing so that food security is not only realized but also preserved [5].

In recent years, food security issues have been linked to various aspects, such as limited natural resources and human resources, increased cases of malnutrition, poverty, natural disasters, socioeconomic instability, quality demands and international trade liberalization, the fulfillment of human rights and so on. In fact, food security is strongly linked to urbanization, changes in piker patterns and lifestyles[6]. These issues encourage the need to create national food security, provinces, districts, sub-districts, and food security at the household level. This becomes more important because it is proven that so far food security has not been fully able to meet the needs of the population.

To strengthen community institutions that support household food security, it is necessary to review the alternative models of poor household food security institutions that are in line with community development demands.

\section{Methodology}

This study is a literature study on 5 research results about the poverty of fishermen in Indonesia. They are: (1) Multi-Dimensional Crisis in Indonesia which caused the poverty of fisherman[7], (2) Fisherman Poverty Trap[8], (3) poor fisherman household in Bone Regency [9], (4) the living standard of fishing communities before and after using technology at Palu Gulf [10], (5) the poverty of fishermen in Sinjai as an impediment to social mobility, and working relation in fishermen community [11], [12].

\section{Result and Discussion}

Institutionalization of household food security of poor fishermen uses two models of relevant approaches in policy making, namely:

Firstly; Zero-sum model is the result of the adaptation of the phenomenon of power transfer in the study of political science. This theory bases itself on the constants that as democratic as any governance, there is always conflict in the management of authority because the amount of authority it has is based more on the political preferences of the elite. If the ruler delegates his authority widely to the public, then the government will lose power to organize and create social orders. The zero-sum game theory reflects the drastic takeover of roles from the rulers to those who had no power. This transfer of authority resulted in the government being exhausted and unable to play a dominant role in public sector management. The implication of the zero-sum approach is that governments are reluctant to empower communities or civil society institutions.

The actualization of the concept is seen when the people who had been only a silent majority and many in interests manipulation, drastically have broad access to participate dominant in the arena of policy formulation. This model is cost-efficient because the delegated authority is the sole responsibility of the party who administers the authority. In the context of institutionalizing food security as a local community institution, pragmatic empowerment policies were born and strive to provide broad authority to the community for planning, implementation and monitoring and evaluation of policies.

The principle is that local governments have insufficient authority and role to intervene in any proposed program offered by citizens. The proposed accommodation level of the program is determined by the ability of the network of community organizations to build strength in the 
decision-making arena. In the context of institutionalizing food security efforts, individual levels are touched by drastic reform through the transfer of authority to increase knowledge, skills, competence and personal motivation sought internally by members of poor fishermen organizations.

At the organizational level, government intervention in the pattern of recruitment, structuring of work structures, distribution of authority and network strengthening is relatively the responsibility of the poorer organizations of the fishermen. The government only plays a role in building the system through legal tools, supporting policies and a conducive environment to control the activities of institutions in community food security activities. This model requires pre-existing conditions of adequate individual capacity and adaptive organizational capacity to negotiate and compete with the government in mobilizing development resources.

Second; Positive-Sum Model. This model is the antithesis of the first model. If in the process of delegation of Zero-Sum model authority resulted in less power and authority for the authorities, then the Positive-Sum model reflects the opposite principle. When capacity building process and empowerment from the ruling party or the government to the weak side, it will further strengthen the power and authority of the first party. In addition, the belief carried on this model is the emphasis of the generative aspect.

The Positive-Sum model focuses more on identifying and solving issues collectively, putting more emphasis on the appraisal on the external and internal environment, and actionoriented. This model entails extensive information gathering, alternative exploration, and emphasizes future implications. The government's strategic authority does not undergo diffracted drastically, but rather on technical and operational matters. The exercise of delegated authority is based on the aspect of out-come effectiveness obtained.

In terms of institutionalization of food security of poor households, the government builds equal partnerships with the community in mobilizing gradual participation expansion and providing technical assistance to the operationalization of institutional empowerment activities. Poor fisherfolk groups seek to utilize the facilities and budgets provided by the government for individual capacity building and organizational structuring. The system level is improved by adjusting to the demands and aspirations of the developing community.

This positive-sum model has preconditions that must be prepared for operational sustainability. The main factor is sufficient time and space because the management activities of this model are done democratically and involve other policy stakeholders. The stages must be strictly assisted and controlled by both parties in order to minimize inconsistent actions in policy operations. The government's intervention action is more technical and the management of strategic and operational authority becomes the internal authority of community groups.

Increased strength and capacity within the food security institution can contribute positively to the government, rather than take over the authority and role of the government. Increased capacity of individuals, organizations, and systems in civil society institutions will be a counterweight to the public sector and the private sector in forging more meaningful partnerships. This condition can be seen in Cohen's article on the role of non-governmental organizations helping to overcome food problems in Africa by buying livestock at high prices and selling meat at subsidized prices[13].

The role of citizens as non-formal institutions becomes important because they have the resources and knowledge. The research results of Puspita prove that Timorese have local knowledge of food management through the utilization of local food that is able to overcome food security problems [14]. 
Thus realizing sustainable food security as an effort to build national integration requires the acceleration of the process of planning change towards better and higher levels over time, phase by stage on an ongoing basis based on or in accordance with the values held by the community[15]. Therefore, it is necessary to develop a food reform institution in a reformative way. That is improvisation through the development and refinement of existing food security institutions.

\section{Conclusion}

There are 2 alternative models of food security institutions offered: firstly, zero-sum model. This model reflects a switch role dramatically from the government to civil power. Thus, this model emphasizes the experience of empowering civil society in the AngloAmerican tradition that sees an association or empowerment institution as an element in society that becomes an inter-mediator between individuals and families with state institutions. Second, the positive-sum model, which focuses more on identifying and solving issues collectively, places more emphasis on the appraisal on the external and internal environment and is action-oriented.

\section{References}

[1] T. Supriatna, "Strategi Pembangunan danKemiskinan, PenerbitRinekaCipta, Jakarta, ., 2000.

[2] J. L. J. Leventon, "Local food sovereignty for global food security? Highlighting interplay challenges," J. Geoforum, vol. 85, pp. 23-26, 2017.

[3] A. Suryana, "Menuju Ketahanan Pangan Indonesia Berkelanjutan 2025: Tantangan dan Penanganannya," Forum Penelit. Agro Ekon., vol. 32, no. 2, pp. 123 - 135, 2014.

[4] L. Morton, E. Bitto, M. Oakland, and M. Sand, "Accessing Food Resources: Rural and Urban Patterns of Giving and Getting Food, Agriculture and Human Values," vol. 25, pp. 107-119, 2008.

[5] S. Martinez et al., Local Food Systems: Concepts, Impacts, and Issues, Economic Research Report 97. Washington, DC: US Department of Agricultur, 2010.

[6] J. Lundqvist, J. Grönwall, and Jägerskog, Water, food security, and human dignity - a nutrition perspective. wedish FAO Committee, Stockholm: Ministry of Enterprise and Innovation, 2015.

[7] M. A. Sallatang, Krisis multidimensional di Indonesia. Makassa: UniversitasHasanuddin, 2002.

[8] A. Arifin, Perangkap Kemiskinan dan Kekerasan Struktural di Balik Relasi Kerja Pinggawa-Sawi. Jakarta: Orbit Press, 2014.

[9] A. Cahaya, "Mengurai Kehidupan Nelayan Miskin di Kabupaten Bone," in Sebuah Studi Sosiologis, 2013.

[10] H. B. Anriani, Pengelolaan Sumber Daya Laut Nelayan Lokal. Makassar: Pena Indis, 2018.

[11] S. A. Kamaruddin, Stratifikasi dan Mobilitas Sosial: Studi Sosiologi Pada Masyarakat Nelayan. Jakarta: Orbit Press, 2009.

[12] S. A. Kamaruddin, "Working relation on fishermen community at Mattiro Labbangeng village," Int. J. Acad. Res. Part B, vol. 6, no. 3, pp. 200-204, 2014.

[13] D. Cohen, "Achieving food security in vulnerable populations," BMJ Br. Med. J., vol. 331, no. 7519, pp. 775-777, 2005. 
[14] D. Puspita, D. Fuka, and S. Notosoedarmo, "Pengetahuan Lokal Masyarakat Timor dalam Upaya Menjaga Ketahanan Pangan Melalui Pangan Lokal," Cakrawala, vol. 6, no. 1, pp. 75-92, 2017.

[15] K. Boratinksa and R. T. Huseynov, "An Innovative Approach To Food Security Policy In Developing Countries," J. Innov. Knowl., vol. 2, no. 1, pp. 39-44, 2017. 